\title{
Представления старшеклассников об инженерном образовании
}

В статье анализируются работы по проблемам профессионального образования и инженерной деятельности. Представлены результаты проведенного эмпирического четырехэтапного исследования по изучению развития представлений учащихся старших классов об инженерном образовании.

Ключевые слова: профессиональное образование, профессиональный выбор, инженерная дестельность.

За последние десятилетия российский социум подвергся не только социальноэкономическим трансформациям. Существенные изменениям произошли в содержательных ориентирах образовательных стратегий. Актуальными стали изменения в приоритетах подготовки специалистов в области гуманитарных, естественных и технических наук. В связи с наметившимся экономическим ростом в современной России возросла потребность в подготовке грамотных специалистов по техническим и инженерным специальностям. Данная потребность обусловила возникновение насущно необходимой переориентации будущих абитуриентов с гуманитарных на инженерно-технические специальности. Ввиду выше сказанного одной из острых проблем психологической науки и практики становится развитие адекватных представлений старшеклассников об инженерном образовании, способных выступить осознанной основой их профессионального выбора.

Проблема профессионального образования образует один из наиболее разработанных пластов психолого-педагогической науки. Ее изучение увязывается с различными аспектами профессионализации человека и рассматривается в контексте профессионального самоопределения (Головаха Е.И., Климов Е.А., Пряжников Н.С., Поваренков Ю.П., Хоменко Н.В., Чистякова С.Н. и др.), профессионального становления (Борисова Е.М., Кудрявцев Т.В., Леднев В.С. и др.) и развития (Асмолов А.Г., Донцов А.И., Коссов Б.Б., Котова И.Б., Фельдштейн Д.И., Шиянов Е.Н. и др.). К настоящему времени выделены различные детерминанты профессионального выбора - объективные и субъективные (Климов Е.А., Пряжников Н.С., Столяренко Л.Д.). Особо отмечается роль профессиональной направленности представляющей собой систему эмоционально-ценностных отношений, побуждающих личность к предпочтению некоторой профессиональной деятельности (Митина Л.М., Брендакова И.В., Вачков И.В. и т.д.).

Изучение инженерной деятельности как предмета профессиональных предпочтений является мало изученной областью психологической науки. Более изученным является процесс подготовки и профессиональной пригодности инженера (Татушкина М.К., Ростунов А.Т.), структура технического интеллекта у инженера (Захарова В.П.), социально-психологические проблемы деятельности инженера (Чугунова Э.С., Чикер В.А., Ядов В.А., Пугач Е.И.), вопросы профессиональной подготовки инженера-педагога (Зеер Э.Ф.), психологические 
резервы инженерной подготовки (Габдреев Р.В.), особенности проявления самоотношения у инженерно-технических работников (Пантелеев С.Р.), динамика личностных характеристик инженера в процессе профессионального становления (Водеников В.А.). Конкретными исследованиями профессионально значимых качеств инженеров занимались К.К. Платонов, В.Д. Шадриков, В.А. Ядов, К.У. Байчоров, Т.А. Майборода и другие исследователи. Какие качества молодых людей способствуют осуществлению ими профессионального выбора в пользу инженерной деятельности, предпочтения ими инженерного образования до настоящего времени остаются вне поля пристального исследования психологопедагогической науки.

Перспективным в этой связи является увязывание обозначенных предпочтений с представлениями старших школьников об инженерном образовании. Проведение разработок в данном направлении стало возможным, благодаря исследовательским результатам, полученным по проблеме психологических представлений в работах трудах отечественных и зарубежных ученых (Агеев В.С., Бодалев А.А., Петренко В.Ф., Попова И.М., Смирнов С.Д., Шихирев П.Н., Дюркгейм Э., Московичи С. И др.).

Практическая востребованность и недостаточная теоретическая разработанность сделала актуальной проблему, положенную в основу нашего исследования: каковы психологические особенности развития представлений об инженерном образовании у старших школьников.

Цель исследования: выявить психологические условия развития представлений об инженерном образовании у старших школьников.

Исследование проводилась на базе средних общеобразовательных школ г. Ростова-на-Дону и нескольких городов Ростовской области (г. Шахты, г. Зерноград, г. Сальск). На их основе была сформирована выборка старшеклассников - учащихся 10 и 11 классов средних общеобразовательных школ общей численностью 210 человек. Средний возраст старшеклассников, вошедших в состав выборки испытуемых, составил 16,8 лет.

Основная гипотеза исследования: представления об инженерном образовании, отражая особенности позиционирования старшеклассником себя в инженерной деятельности, выступают психологическим условием его готовности к осуществлению соответствующего профессионального выбора.

В рамках нашего исследования были использованы следующие методики: «Дифференциально-диагностический опросник» Е.А. Климова, «Опросник профессиональных предпочтений» в модификации Дж. Голланда, «Ценностные ориентации» М. Рокича.

Исследование проводилось с 2006 по 2010 гг. и включала в себя следующие этапы.

1. Подготовительный этап (2006-2007 гг.) предусматривал конкретизацию предметной области исследования, определение цели и задач исследования, установление теоретических основ исследовательской работы, разработку методических аспектов эмпирической части исследования. 
2. Констатирующий этап эмпирической части исследования (2007-2008 гг.) включал формирование экспериментальной выборки испытуемых, выявление основного поля представлений старшеклассников об инженерном образовании, установление факторов их развития, выделение структуры представлений старшеклассников о качествах, необходимых для успешного выполнения инженерной деятельности, и уровня их соответствия личностным качествам старшеклассников.

3. Формирующий этап эмпирической части исследования (2008-2009 гг.) предусматривал разработку и апробацию программы развития представлений старшеклассников об инженерном образовании.

4. Заключительный этап исследования (2009-2010 гг.) состоял в проведении анализа и обобщения результатов теоретической и эмпирической части исследования, осуществлении их интерпретации и представления в виде диссертационной работы.

В проведенном исследовании получены результаты, позволившие сделать следующие выводы.

1. Представления старшеклассников об инженерном образовании представляют собой сложную интеграцию складывающегося у них субъективного отражения особенностей инженерной деятельности и самооценки возможности личностной самореализации при ее выполнении.

2. Представления старшеклассников об инженерном образовании включают в себя несколько смысловых групп, объединяющих их знания об особенностях инженерной деятельности и содержания профессиональной подготовки, субъективную позицию относительно своего соответствия инженерной деятельности и возможности самореализации на личностном уровне с помощью инженерного образования. Первые две смысловые группы образуют когнитивный компонент, а две последующие - ценностно-смысловой компонент представлений старшеклассников об инженерном образовании.

3. Развитие представлений старшеклассников об инженерном образовании подвержено влиянию ряда объективных и субъективных факторов. К объективным факторам развития представлений старшеклассников об инженерном образовании относятся: наличие у родителей или других близких родственников инженерного образования; присутствие в населенном пункте вуза, позволяющего получить инженерное образование. Субъективными факторами развития представлений старшеклассников об инженерном образовании являются: уверенность в обладании качествами, востребованных инженерной деятельностью; направленность на профессии (по Е.А. Климову); профессиональные предпочтения (по Дж. Голланду); ценностные ориентации (по М. Рокичу).

4. Представления старшеклассников об инженерном образовании оказывают влияние на их готовность к выбору данного образования. Наибольшее влияние на данный выбор оказывает ценностно-смысловой компонент представлений старшеклассников об инженерном образовании. 
5. Выбор старшеклассниками инженерного образования предусматривает выделение профессионально-личностных качеств, необходимых для успешного выполнения инженерной деятельности. Данные качества на субъективном уровне включают в себя группы деловых, эмоционально-волевых и адаптационных качеств.

6. Развитие представлений старшеклассников об инженерном образовании проходит успешно при условии сочетания практики расширения их информированности о соответствующей сфере профессиональной деятельности и развития уверенности старшеклассников в своем соответствии требованиям профессии.

\section{Литература}

1.

2.

3. 